\title{
KONSEP PENGEMBANGAN INFRASTRUKTUR TRANPORTASI KAWASAN PERBATASAN DI PROPINSI NUSA TENGGARA TIMUR DENGAN MENGACU PADA KEBIJAKAN MP3EI ${ }^{1)}$
}

\author{
Oleh:
}

\author{
Kusa Bill Noni Nope, ST., MT ${ }^{2)}$ \\ e-mail:kusa_nope@yahoo.co.id
}

\begin{abstract}
abstrak
Data menunjukkan bahwa pergerakan laju pertumbuhan ekonomi Indonesia dalam 5 tahun terakhir (tahun 2008-2012) berturut-turut: 5,3\%; 5,4\%; 6,9\%; 6,5\%; dan 6,4\% relatif stabil di kisaran angka 5 $-6 \%$ namun ada kecenderungan menurun. Penurunan ini selain karena pengaruh krisis di Amerika, Eropa dan Timur Tengah, juga akibat RPJMN maupun RPJPN yang belum diimplementasikan secara baik. Menyadari hal ini, Pemerintah mengeluarkan Perpres No. 32 Tahun 2011 tentang Masterplan Percepatan dan Perluasan Pembangunan Ekonomi Indonesia (MP3EI) Tahun 2011-2025, untuk mempercepat capaian target pertumbuhan ekonomi Indonesia di kisaran angka 8-10\% per tahun. Dokumen ini harus dipahami oleh 3 pilar pelaku MP3EI (pemerintah dan pemerintah daerah, pelaku bisnis, dan akademisi) sebagai dokumen kerja yang komplemen dari dokumen RPJPN Tahun 2005-2025.

Dalam penerapannya, kebijakan MP3EI nampaknya akan dihadapkan pada lima tantangan kebijakan lainnya yakni Otonomi Daerah, Sistem Transportasi Wilayah Kawasan, RTRWN dan Sistranas, RTRW Propinsi/Kabupaten/Kota, serta Pengembangan Sarana dan Prasarana Multimoda (infrastruktur transportasi). Makalah ini hanya akan membahas secara konsep pengembangan infrasruktur transportasi di Propinsi NTT. Permasalahan yang akan dibahas adalah sejauhmana kebutuhan pengembangan jaringan jalan di NTT, didasarkan pada Standar Pelayanan Minimal (SPM) Jalan, khususnya aspek aksesibilitas dan mobilitas.

Hasil analisa menunjukkan bahwa indeks aksesibilitas maupun indeks mobilitas jaringan jalan eksisting untuk seluruh Kabupaten/Kota di NTT telah mencukupi nilai minimum yang ditetapkan dalam SPM jalan, namun belum terhubungkan antara satu wilayah dengan wilayah lainnnya. Selain itu, pada dasarnya PDRB perkapita di Propinsi NTT masih cukup rendah yakni hanya sekitar 35\% dibandingkan dengan kondisi di Indonesia. Hal ini mengingat jaringan jalan tidak terhubung antar satu wilayah dengan wilayah lain akibat hambatan geografis (kepulauan). Perlu adanya pengembangan sarana dan prasarana multimoda sesuai kondisi geografis NTT sebagai wilayah kepulauan. Khusus untuk daerah perbatasan, maka perlu dipertimbangkan untuk pengembangan kawasan di Morotaing, Apui, Wini, Oelolok dan Betun sebagai kota dengan Hirarki/Jenjang III.
\end{abstract}

\section{PENDAHULUAN}

Undang-Undang Nomor 17 Tahun
2007 tentang Rencana Pembangunan
Jangka Panjang Nasional (RPJPN) Tahun
$2005-2025$ sesungguhnya memiliki aras
dan tujuan pemeritah guna meningkatkan
daya saing perekonomian nasional yang
lebih solid. Seiring perjalanan waktu, data
dari website Kementerian Sekretaris
Negara RI menunjukkan bahwa

pergerakan laju pertumbuhan ekonomi Indonesia dalam 5 tahun terakhir (tahun 2008-2012) berturut-turut: 5,3\%; 5,4\%; $6,9 \% ; 6,5 \%$; dan 6,4\%. Dari data tersebut memang angka pertumbuhan ekonomi Indonesia relatif stabil di kisaran angka 5$6 \%$ namun ada kecenderungan menurun akibat pengaruh ekonomi global. Menyadari hal ini, Pemerintah terus mendorong dan mengambil sikap 
antisipatif dan langkah kebijakan untuk mempercepat capaian target pertumbuhan ekonomi Indonesia dengan scenario optimis di kisaran angka pertumbuhan $8-10 \%$.

Tahun 2011 terjadi penurunan angka pertumbuhan ekonomi Indonesia dari $6,9 \%$ ke $6,5 \%$ bahkan terus menurun ke level $6,4 \%$ di tahun 2013 , selain karena pengaruh krisis di Amerika, Eropa dan Timur Tengah, juga diakibatkan oleh RPJMN maupun RPJPN yang belum diimplementasikan secara baik. Untuk menekan laju penurunan, mempertahankan diri dari serangan krisis (trauma 1998), sekaligus juga mempercepat pembangunan maka Pemerintah mengeluarkan Perpres No. 32 Tahun 2011 tentang Masterplan Percepatan dan Perluasan Pembangunan Ekonomi Indonesia (MP3EI) Tahun 20112025. Dokumen ini sesungguhnya harus dipahami oleh 3 pilar pelaku MP3El (pemerintah dan pemerintah daerah, pelaku bisnis, dan akademisi) sebagai dokumen kerja yang komplementer, bukan pengganti, dari dokumen RPJPN Tahun 2005-2025.

Perlu dipahami bersama bahwa MP3El sebagaimana dimaksud dalam Perpres No. 32 Tahun 2011, Pasal 2, berfungsi sebagai: (i) acuan bagi menteri dan pimpinan lembaga pemerintah nonkementerian untuk menetapkan kebijakan sektoral dalam rangka pelaksanaan percepatan dan perluasan pembangunan ekonomi Indonesia di bidang tugas masing-masing, yang dituangkan dalam dokumen rencana strategis kementerian/lembaga pemerintah nonkementerian sebagai bagian dari dokumen perencanaan pembangunan; dan (ii) acuan untuk penyusunan kebijakan percepatan dan perluasan pembangunan ekonomi Indonesia pada tingkat provinsi dan kabupaten/kota terkait. Jadi dokumen MP3EI adalah dokumen acuan penyusunan kebijakan sektoral sekaligus sebagai dokumen tak terpisahkan dari dokumen perencanaan pembangunan.

Keseriusan pemerintah juga ditunjukkan melalui instruksi langsung Presiden RI kepada 3 pilar pelaku MP3EI yaitu pemerintah dan pemerintah daerah, pelaku bisnis, dan akademisi, yang mampu menghasilkan sekurangkurangnya invensi (belum dapat disebut inovasi jika belum sampai ke pengguna) agar mendukung pengembangan program utama di setiap koridor ekonomi. Bahkan, dana pun telah dialokasikan kepada 3 pilar tersebut dan jika disinergikan tentunya akan dapat mempercepat pencapaian tujuannya yaitu percepatan dan perluasan pembangunan ekonomi Indonesia. Percepatan dan perluasan pembangunan ekonomi ini dilakukan melalui pengembangan 8 program utama yaitu pertanian, pertambangan, energi, industri, kelautan, pariwisata, dan telematika, serta pengembangan kawasan strategis, serta melingkupi 22 kegiatan ekonomi utama di dalamnya.

Strategi pelaksanaan MP3EI pada prinsipnya adalah dengan mengintregasikan 3 (tiga) elemen utama, yaitu (1) mengembangkan potensi ekonomi wilayah di 6 Koridor Ekonomi; (2) memperkuat konektivitas nasional yang terintregasi secara lokal dan terhubung secara global (locally integrated, globally connected); memperkuat kemampuan sumber daya manusia (SDM) dan iptek nasional untuk mendukung pengembangan program utama di setiap koridor ekonomi. Tentunya, dengan melihat antusiasme pemerintah RI atas program ini maka ada hal menarik yang penulis ingin menggugah sekaligus membahasnya dalam makalah ini adalah terkait dengan konsep penerapan program ini. Hal ini terutama bilamana dikaitkan dengan karakteristik Wilayah Propinsi Nusa Tenggara Timur (NTT) sebagai sebuah propinsi kepulauan sekaligus propinsi terluar dan terdepan yang berbatasan dengan Negara Timor Leste dan Australia. 


\section{KERANGKA KEBIJAKAN MP3EI}

Dalam rangka merumuskan strategi dan kebijakan, MP3EI mempertimbangkan Posisi geo-strategis Indonesia dalam skala regional maupun global. Posisi geo-strategis tersebut membentuk keunggulan dan keunikan masing -masing pulau besar yang akan menjadi pilar utama dalam rangka mencapai visi 2025 .
Perwujudannya dapat dimaknai dengan pendefinisian peran strategis masing-masing pulau besar yang nantinya membentuk 6 koridor ekonomi. Dengan demikian, pengembangan 6 koridor ekonomi (Gambar 1) harus diselenggarakan secara terintegrasi, tidak terpisah-pisah untuk memaksimalkan percepatan dan perluasan pembangunan ekonomi di seluruh tanah air.

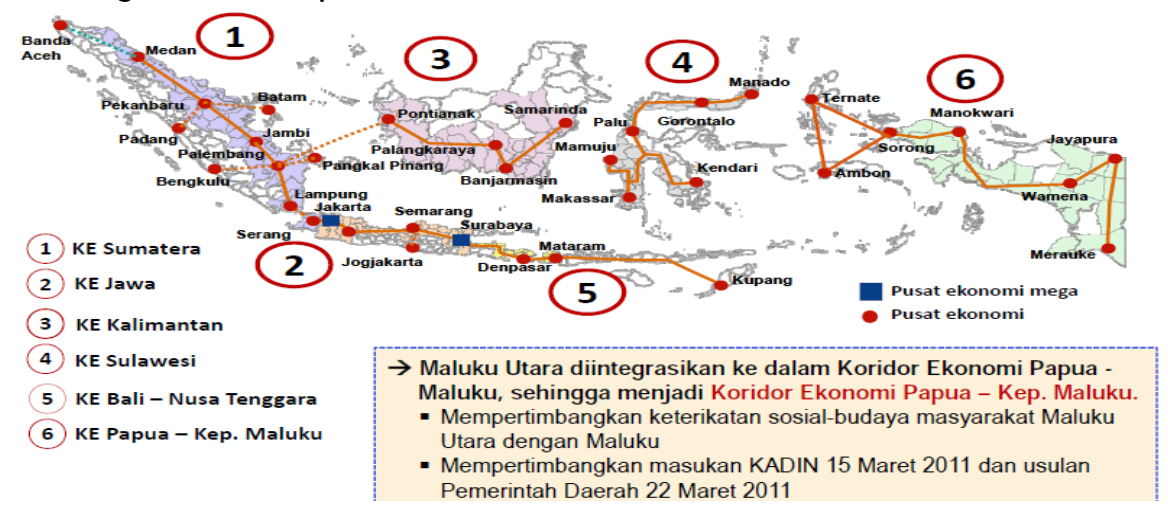

Gambar 1 Pengembangan 6 Koridor Ekonomi Indonesia

(Sumber: Kementerian Koordinator Bidang Perekonomian, 2011)

Berdasarkan 6 koridor pengembangan ekonomi Indonesia maka masing-masing koridor ekonomi dipetakan pula menurut tema pembangunan didasarkan pada keunggulan dan posisi startegis masingmasing wilayah serta sebaran kegiatan utama pengembangan ekonominya. Tema pembangunan masing-masing koridor ekonomi berikut sebaran kegiatan utamanya adalah:

1. Koridor Sumatera, dengan tema pembangunannya yakni sentra produksi dan pengolahan hasil bumi dan lumbung energy nasional. Sebaran kegitan utamanya adalah kelapa sawit, karet, batubara, besi-baja, JSS;

2. Koridor Jawa, dengan tema pembangunannya yakni pendorong industri dan jasa nasional. Sebaran kegitan utamanya adalah indsutri manufaktur-mineral, tekstil, permesinan transportasi, perkapalan, alutsista, telematika, dan metropolitan jabodetabek;
3. Koridor Kalimantan, dengan temanya yakni pusat produksi dan pengolahan hasil tambang, serta lumbung energi nasional, berikut sebaran kegiatan utamanya pada kelapa sawit, batubara, alumina/bauksit, migas, perkayuan, dan besi-baja;

4. Koridor Sulawesi, dengan temanya adalah pusat produksi dan pengolahan hasil pertanian, perkebunan dan perikanan, serta pertambangan nikel nasional;

5. Koridor Bali-Nusa Tenggara, dimana tema pembangunannya adalah pintu gerbang pariwisata dan pendukung pangan nasional. Sebaran kegiatan utama koridor ini adalah pariwisata, peternakan, dan perikanan, serta

6. Koridor Papua-Kepulauan Maluku, dengan tema pusat pengembangan pangan, perikanan, energi dan pertambangan nasional, dimana sebaran kegiatan utama koridor ini meliputi food estate, tembaga, 
peternakan, perikanan, migas, dan nikel.

Dengan demikian, sesuai fungsinya maka sesungguhnya diharapkan ke-3 pilar pelaku MP3El (pemerintah dan pemerintah daerah, pelaku bisnis, dan akademisi) dapat menjadikan dokumen MP3El sebagai acuan untuk menyusun dan menetapkan kebijakan sektoral pembangunan dalam dokumen perencanaan pembangunan guna percepatan dan perluasan pembangunan ekonomi regional atau wilayah sebagai bagian tak terpisahkan dari semangat pembangunan ekonomi Indonesia.

\section{KEBIJAKAN PENGEMBANGAN INFRASTRUKTUR TRANSPORTASI}

\subsection{Interaksi Infrastruktur dan Pembangunan Ekonomi}

Berbicara mengenai pertumbuhan ekonomi tentunya tidak terlepas dari peran pembangunan ekonomi dan pentingnya dukungan infrastruktur (termasuk transportasi) sebagai katalisator pembangunan. Widayatin (2005) memaparkan beberapa contoh kasus pentingnya peran infrastruktur bagi pembangunan ekonomi, misalnya:

(1) Presiden Hoover, USA 1930, menolak membangun infrastruktur, maka hal yang terjadi adalah: Pengangguran meningkat dari 8 Juta -> 15 Juta orang, Pendapatan nasional turun dari USD 82 -> USD 40 Milyar, Harga saham jatuh $80 \%$, Produktivitas nasional turun $50 \%$;

(2) Presiden Roosevelt, pengganti Hoover, USA 1933, mengembangkan program infrastruktur dengan judul "the New Deal", hasilnya adalah: mampu memberi tambahan lapangan kerja bagi 6 Juta orang, pendapatan nasional naik dari USD $40 \mathrm{M}$ ke USD 60 Milyar;

(3) Belanda, pada masa krisis di era tahun 1930-an, tetap fokus untuk membangun jalan, tanggul, dan kanal. Hasilnya adalah industri bahan bangunan meningkat berdampak pada peningkatan industri jasa konstruksi, demikian akhirnya memicu pertumbuhan industri peralatan berat.

(4) Inggris, Afrika Selatan, dan beberapa negara lain, bahkan Negara Asean seperti Singapura, Malaysia, dan terakhir Vietnam maju sangat pesat akibat keseriusan pemerintahnya dalam menerapkan kebijaksanaan pengembangan infrastruktur.

Gambaran diatas sesungguhnya hanya sebagian kecil fakta yang bukan untuk menakuti tetapi untuk menunjukkan betapa pentingnya infrastruktur sebagai alat pengembangan wilayah (infrastructure as tool as regional development). Dalam memacu pertumbuhan ekonomi suatu negara yang tentunya dimulai dari pengembangan suatu wilayah.

\subsection{Kebijakan Pengembangan Infrastruktur Transportasi}

Pengembangan infrastruktur transportasi sesungguhnya tidak terlepas dari pengembangan sistem jaringan transportasi. Ketersediaan infrastruktur, seperti jalan, pelabuhan, bandara, sistem penyediaan tenaga listrik, irigasi, sistem penyediaan air bersih, sanitasi, dan sebagainya merupakan Social Overhead Capital. Sebagai modal sosial maka infrastruktur memiliki keterkaitan yang sangat kuat dengan tingkat perkembangan wilayah, antara lain dicirikan oleh laju pertumbuhan ekonomi dan kesejahteraan masyarakat. Hal tersebut dapat dilihat dari kenyataan bahwa daerah yang mempunyai kelengkapan sistem infrastruktur yang lebih baik, mempunyai tingkat laju pertumbuhan ekonomi dan kesejahteraan masyarakat yang lebih baik pula, bila dibandingkan dengan daerah yang 
mempunyai kelengkapan infrastruktur yang terbatas. Dengan demikian maka penyediaan infrastruktur merupakan faktor kunci dalam mendukung pembangunan nasional.

Dalam level operasional, sejumlah permasalahan kebijakan pengambangan infrastruktur transportasi di tingkat propinsi/kabupaten/kota membutuhkan adanya program penanganan yang terpadu. Seharusnya, skema kebijakan dan program jangka pendek "idealnya" merupakan bagian dari skema kebijakan jangka panjang dari rencana pengembangan sistem jaringan transportasi secara keseluruhan. Hal ini mengharuskan adanya dokumen perencanaan strategis terkait dengan sistem transportasi wilayah. Dalam rangka membentuk suatu Sistem Transportasi Wilayah (sistrawil) yang terpadu dan berkesinambungan, maka pemecahan permasalahan sistem jaringan transportasi yang ada harus juga memperhatikan hal-hal sebagai berikut (Gambar 2).

Masalah dan isu pengembangan sistem jaringan transportasi wilayah yakni:

(1) Isu otonomi daerah (meningkatkan peran kabupaten/kota);

(2) Sistem Transportasi Wilayah kawasan lebih luas;

(3) Rencana Tata Ruang Wilayah Nasional (RTRWN) dan Sistem Transportasi Nasional (Sistranas);

(4) Rencana Tata Ruang Wilayah Propinsi dan Kabupaten/Kota (RTRW Propinsi dan RTRW Kabupaten/Kota); dan

Pengembangan sarana dan prasarana multi moda.

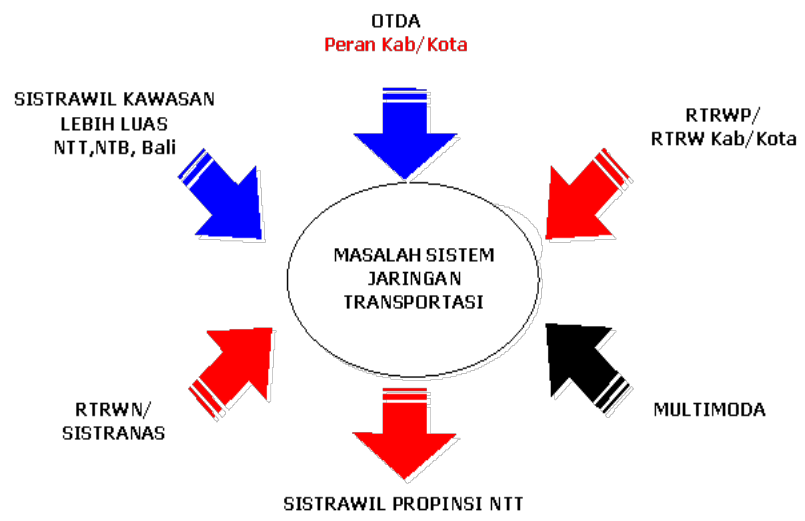

Gambar 2 Masalah dan Isu Pengembangan Sistem Jaringan Transportasi (Sumber: Dardak, 2005, diolah)

Seiring dengan diberlakukannya UU No.32 Tahun 2004 tentang Pemerintahan Daerah maka akan terjadi perubahan mendasar dalam pengelolaan sistem transportasi. Katakanlah dalam proses perencanaan jaringan transportasi nasional/propinsi tidak dapat lagi bersifat top-down dengan pemerintah pusat/propinsi sebagai aktor utamanya. Pendekatan bottom-up akan lebih cocok untuk mencerminkan adanya demokratisasi dalam proses pengambilan kebijakan dan desentralisasi wewenang pemerintahan ke Kabupaten/Kota. Perubahan ini pun akan mengalami suatu tantangan tersendiri bila keinginan pemerintah Kabupaten/Kota sebagai pemilik daerah otonom dengan keinginan "mengatur rumah tangganya sendiri" dengan kebijakan pengembangan ekonomi nasional melalui kebijakan MP3El.

Untuk itu, dalam mengembangkan kebijakan pengembangan infrastruktur transportasi maka setidaknya terdapat 2 (dua) hal yang harus diperhatikan, yaitu: 
(1) Partisipatif: dengan diberlakukannya otonomi daerah, maka bagaimanapun juga aspirasi dan keinginan dari kabupaten/kota harus dipertimbangkan. Namun demikian, penyelenggaraannya harus tetap dalam konteks pengembangan sistem jaringan transportasi wilayah propinsi atau nasional termasuk kebijakan MP3EI. Butir ini mengimplikasikan bahwa dalam perencanaan program pengembangan sistem jaringan transportasi, sekarang ini perlu adanya perubahan strategi setidaknya untuk menyikapi kedua persoalan diatas. Paradigma perencanaan harus lebih partisipatif yang mampu mencerminkan adanya kesepakatan dari semua pihak yang terlibat, baik dari tingkat nasional dan propinsi, maupun dari kabupaten/kota.

(2) Bertahap: sesuai dengan kemampuan pendanaan yang ada, maka tidak memungkinkan semua keinginan dalam mengembangkan sistem jaringan transportasi dapat diwujudkan sekaligus. Untuk itu, pelaksanaan pembangunan harus dilakukan seara bertahap sesuai dengan prioritas. Butir ini mengimplikasikan perlunya dikembangkan suatu alat bantu pengambian keputusan yang mampu menyusun usulan program pengembangan sistem jaringan transportasi sesuai dengan prioritas yang sudah menjadi kesepakatan bersama dan telah dicapai pada butir (1).

Untuk menyusun daftar prioritas tersebut, dibutuhkan adanya sejumlah krirteria yang mampu menyeleksi usulan yang ada secara fair dan telah memperhatikan keinginan semua pihak yang berkepentingan (stakeholders). Salah satu pendekatan perencanaan yang memungkinkan diakomodasikannya sejumlah kepentingan dan sejumlah kriteria dalam proses pengambilan keputusan adalah Analisis Multi-Kriteria (AMK).

\subsection{Konsep Perencanaan Partisipatif}

Berpulang pada keterkaitan antara kebijakan pengembangan tata ruang, MP3EI dan sistem jaringan transportasi dan berlakunya otonomi daerah, maka strategi kebijakan pengembangan sistem jaringan transportasi sudah harus mulai meninggalkan pendekatan top-down, dengan pemerintah pusat sebagai aktor utamanya. Pendekatan harus lebih banyak menggunakan pendekatan bottom-up sehingga lebih mencerminkan adanya demokratisasi dalam proses pengambilan kebijakan dan desentralisasi wewenang pemerintahan. Selain itu, strategi kebijakan pengembangan sistem transportasi wilayah (sebagai tulang punggung pengembangan ekonomi wilayah) yang melibatkan banyak pihak sebagai suatu committed master-plan sudah harus dilaksanakan. Hal ini mengingat bahwa keterkaitan antara sektor transportasi dengan sektor kewilayahan maupun pengembangannya mengharuskan pengelolaannya tidak bisa dilakukan oleh satu pihak yang berwenang.

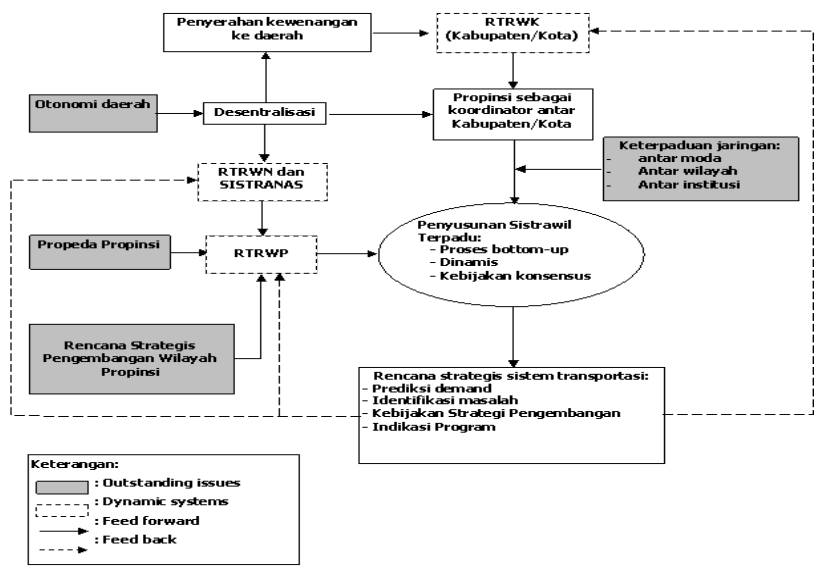




\section{Gambar 3 Usulan Penyusunan Konsep Sistem Transportasi Wilayah Terpadu (Sumber: LP-/TB, 2001, diolah)}

\begin{abstract}
Namun demikian sesuai dengan konsep Sistranas yang terpadu secara nasional, maupun pengembangan ekonomi melalui kebijakan MP3EI, maka pengembangan sistem jaringan
\end{abstract} transportasi di tingkat daerah harus tetap mengacu kepada pola tata ruang, sistem transportasi dan koridor pengembangan ekonomi secara nasional. Hal ini menunjukkan aspek perencanaan yang bersifat top-down, di mana konsep pengembangan secara makro di tingkat pusat harus tetap diacu. Dengan demikian, pengembangan system jaringan transportasi wilayah di tingkat propinsi dan tingkat di bawahnya sebaiknya dilakukan sebagai gabungan antara pendekatan bottom-up dengan top-down.

Secara top-down masalah dapat diidentifikasi dari kesenjangan antara kondisi yang menjadi harapan/tujuan dengan kondisi yang terjadi sekarang. Bila diinginkan terukur, maka cakupan tujuan atau harapan yang sifatnya selalu kualitatif atau abstrak perlu diterjemahkan menjadi tujuan yang terukur (quantified objective), berupa indikator-indikator kinerja sistem. Secara umum usulan konsep dapat divisualisasikan melalui Gambar 3. Konsep berawal dengan menangkap konsepsi otonomi daerah dan kebijakan MP3El sebagai masukan dari rencana pengembangan wilayah Kabupaten/Kota yang akan menjadi masukan utama dalam menyusun kerangka pengembangan Sistem Transportasi Wilayah Propinsi.

\subsection{Analisis Multi-Kriteria (AMK) Dalam Pengembangan Konsep Sistrawil}

Pengambilan keputusan dalam perencanaan sistem transportasi akan dihadapkan kepada sejumlah variabel yang kompleks sesuai sifat ke-multi-an dari sistem transportasi. Setidaknya keputusan yang diambil harus mampu mencerminkan adanya kompromi, di mana kehendak (aspirasi) daerah kabupaten/kota harus dipadukan dengan kebutuhan propinsi untuk menyelaraskan aspirasi tersebut secara lintas daerah dan lintas sektoral. Hal ini menjadi lebih kompleks karena Propinsi mengemban tugas dari pusat untuk mengkoordinasikan pengembangan sistem transportasi di daerah sehingga menjalin sistem transportasi yang terpadu. Selain batasan normatif di atas terdapat juga batasan teknis yang harus dipertimbangkan seperti kebutuhan perjalanan, biaya penyediaan/ konstruksi/ operasi, dan besarnya manfaat ekonomi yang ditimbulkan dari usulan-usulan pengembangan yang diajukan. Di samping itu, dalam konteks pengembangan wilayah, sistem transportasi harus pula dilihat kinerjanya dalam mendukung pengembangan kawasan andalan yang ditetapkan.

Analisis Multi Kriteria (Multi Criteria Analysis) merupakan alternatif teknik yang mampu menggabungkan sejumlah kriteria dengan besaran yang berbeda (multi-variable) dan dalam persepsi pihak terkait yang bermacam-macam (multi-facet). Dalam penelitian ini teknik analisis multi kriteria digunakan untuk menganalisis dan melakukan prioritasi terhadap sejumlah usulan pengembangan sistem transportasi yang digali dari daerah. Bagan alir analisis multi kriteria ini disampaikan pada Gambar 4. 
Alternatif usulan pengembangan diperoleh dari hasil survei ke daerah dan propinsi, yang kemudian dengan model transportasi akan diperkirakan kinerjanya sepanjang waktu tinjauan. Tampilan kinerja tersebut akan dinilai oleh para pakar (expert judgement) terhadap kriteria pengembangan yang disarikan dari konsep pengembangan jaringan jalan, seperti dari Sistranas, RTRW, dan kebijakan lainnya. Kriteria pengembangan dipersepsikan kepada para pengambil keputusan di daerah untuk menghasilkan bobot relatif tingkat kepentingan antar kriteria. Melalui proses AMK akan diperoleh perangkingan antar prioritas sesuai dengan kemampuannya dalam memenuhi tingkat kepentingan kriteria yang dikembangkan.

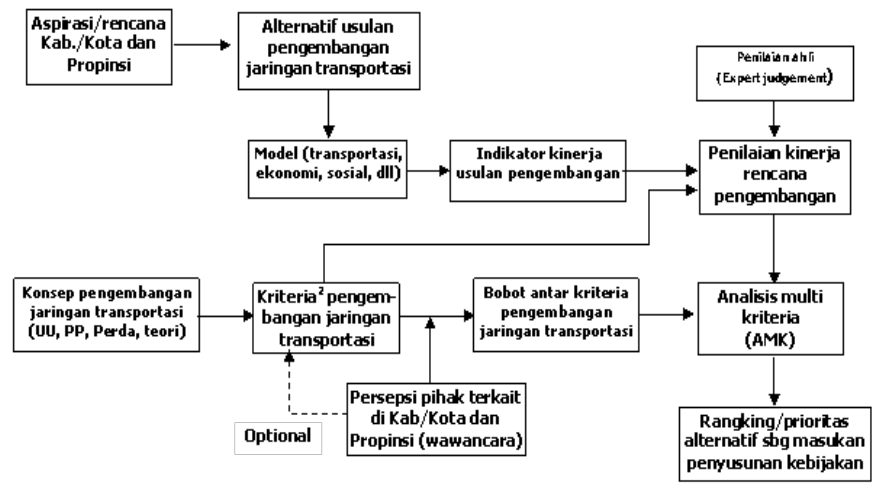

Gambar 3 Usulan Penyusunan Konsep Sistem Transportasi Wilayah Terpadu (Sumber: LP-/TB, 2001, diolah)

Namun demikian sesuai dengan konsep Sistranas yang terpadu secara nasional, maupun pengembangan ekonomi melalui kebijakan MP3El, maka pengembangan sistem jaringan transportasi di tingkat daerah harus tetap mengacu kepada pola tata ruang, sistem transportasi dan koridor pengembangan ekonomi secara nasional. Hal ini menunjukkan aspek perencanaan yang bersifat top-down, di mana konsep pengembangan secara makro di tingkat pusat harus tetap diacu. Dengan demikian, pengembangan system jaringan transportasi wilayah di tingkat propinsi dan tingkat di bawahnya sebaiknya dilakukan sebagai gabungan antara pendekatan bottom-up dengan top-down.

Secara top-down masalah dapat diidentifikasi dari kesenjangan antara kondisi yang menjadi harapan/tujuan dengan kondisi yang terjadi sekarang. Bila diinginkan terukur, maka cakupan tujuan atau harapan yang sifatnya selalu kualitatif atau abstrak perlu diterjemahkan menjadi tujuan yang terukur (quantified objective), berupa indikator-indikator kinerja sistem. Secara umum usulan konsep dapat divisualisasikan melalui Gambar 3. Konsep berawal dengan menangkap konsepsi otonomi daerah dan kebijakan MP3EI sebagai masukan dari rencana pengembangan wilayah Kabupaten/Kota yang akan menjadi masukan utama dalam menyusun kerangka pengembangan Sistem Transportasi Wilayah Propinsi.

\subsection{Analisis Multi-Kriteria (AMK) Dalam Pengembangan Konsep Sistrawil}

Pengambilan keputusan dalam perencanaan sistem transportasi akan dihadapkan kepada sejumlah variabel yang kompleks sesuai sifat ke-multi-an dari sistem transportasi. Setidaknya keputusan yang diambil harus mampu mencerminkan adanya kompromi, di mana kehendak (aspirasi) daerah kabupaten/kota harus dipadukan dengan kebutuhan propinsi untuk menyelaraskan aspirasi tersebut secara lintas daerah dan 
lintas sektoral. Hal ini menjadi lebih kompleks karena Propinsi mengemban tugas dari pusat untuk mengkoordinasikan pengembangan sistem transportasi di daerah sehingga menjalin sistem transportasi yang terpadu. Selain batasan normatif di atas terdapat juga batasan teknis yang harus dipertimbangkan seperti kebutuhan perjalanan, biaya penyediaan/ konstruksi/ operasi, dan besarnya manfaat ekonomi yang ditimbulkan dari usulan-usulan pengembangan yang diajukan. Di samping itu, dalam konteks pengembangan wilayah, sistem transportasi harus pula dilihat kinerjanya dalam mendukung pengembangan kawasan andalan yang ditetapkan.

Analisis Multi Kriteria (Multi Criteria Analysis) merupakan alternatif teknik yang mampu menggabungkan sejumlah kriteria dengan besaran yang berbeda (multi-variable) dan dalam persepsi pihak terkait yang bermacam-macam (multi-facet). Dalam penelitian ini teknik analisis multi kriteria digunakan untuk menganalisis dan melakukan prioritasi terhadap sejumlah usulan pengembangan sistem transportasi yang digali dari daerah. Bagan alir analisis multi kriteria ini disampaikan pada Gambar 4. Alternatif usulan pengembangan diperoleh dari hasil survei ke daerah dan propinsi, yang kemudian dengan model transportasi akan diperkirakan kinerjanya sepanjang waktu tinjauan. Tampilan kinerja tersebut akan dinilai oleh para pakar (expert judgement) terhadap kriteria pengembangan yang disarikan dari konsep pengembangan jaringan jalan, seperti dari Sistranas, RTRW, dan kebijakan lainnya. Kriteria pengembangan dipersepsikan kepada para pengambil keputusan di daerah untuk menghasilkan bobot relatif tingkat kepentingan antar kriteria. Melalui proses AMK akan diperoleh perangkingan antar prioritas sesuai dengan kemampuannya dalam memenuhi tingkat kepentingan kriteria yang dikembangkan.

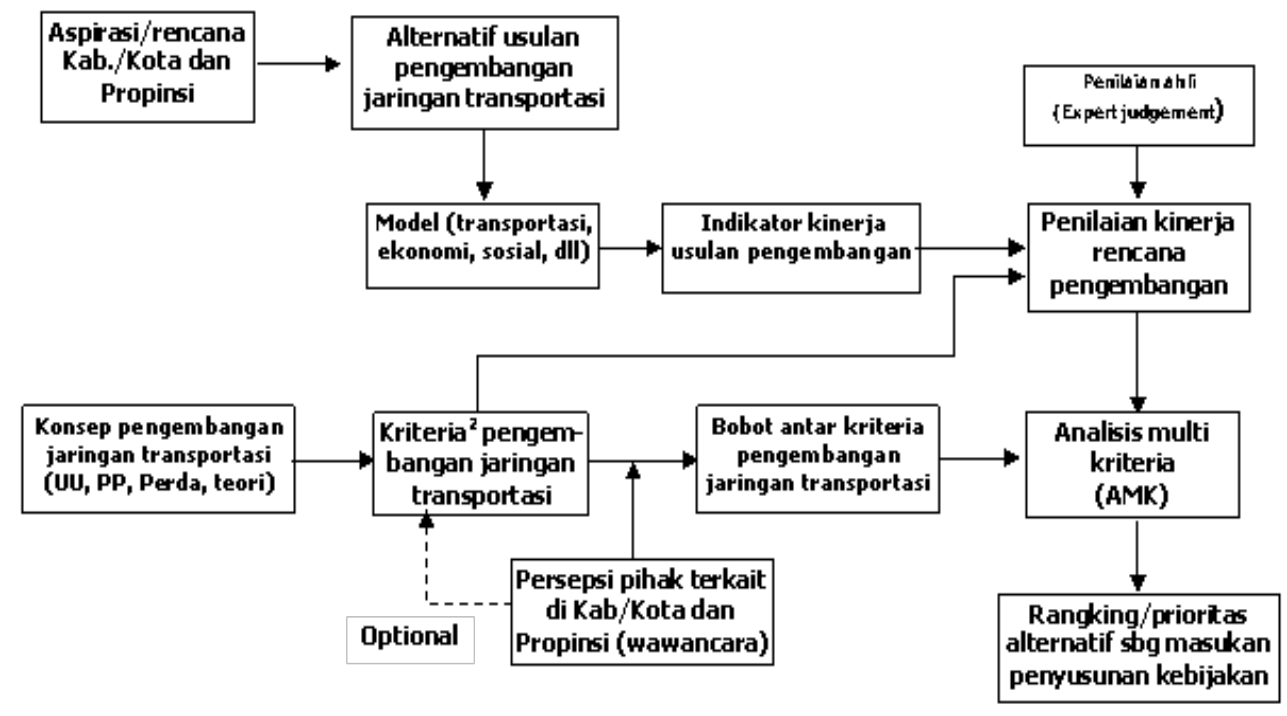

Gambar 4 Proses AMK dalam Penyusunan Kebijakan Pengembangan Sistem Transportasi Wilayah (Sistrawil)

(Sumber: Tamin, 2000)

\section{KONSEP PENGEMBANGAN INFRASTRUKTUR TRANSPORTASI DI PROPINSI NUSA TENGGARA TIMUR}

Sistem transportasi merupakan prasarana dasar (basic infrastructure) bagi pelayanan masyarakat (public service) yang dampaknya bersifat multidimensional. Kemultian penyelenggaraan sistem transportasi, tidak hanya terkait dengan sistem multi-moda yang 
menyatukan serangkaian moda transportasi: darat, laut, dan udara, tetapi dalam perencanaannya juga harus mencerminkan keputusan yang dapat diterima semua pihak yang memiliki cara pandang yang berbeda (multi-facet), dengan mempertimbangkan variabel dampak dan manfaat yang beragam (multi-variables), melibatkan sejumlah pihak/insitusi yang mencerminkan aspek multi-sektoral.

\subsection{Identifikasi Kebutuhan Pengembangan Infrastruktur Jalan di NTT}

Untuk mengidentifikasi kebutuhan penanganan jalan $\mathrm{N} / \mathrm{P}$, maka diperlukan adanya analisis mengenai kondisi fisik dan pelayanan jalan yang ada saat ini. Sehingga atas dasar analisis ini akan dapat disusun kebutuhan pengembangan jalan di masa datang. Dalam idealisasi pengembangan jalan sebagai sistem infrastruktur dasar (basic infrastructure) maka di era otonomi daerah, pemerintah pusat telah mendelegasikan sejumlah kewajiban pelayanan masyarakat kepada pemerintah daerah. Dalam hal ini untuk menjaga terpenuhinya kualitas pelayanan kepada masyarakat, khususnya yang terkait dengan transportasi jalan, instansi teknis terkait (Kementerian PU) telah mengeluarkan SPM (standar pelayanan minimum) jalan. SPM jalan ini secara konseptual diharapkan menjadi salah satu acuan bagi pemerintah daerah untuk mengembangkan infrastruktur jaringan jalan di wilayahnya (Tabel 2).

Tabel 2 SP M Jaringan dan Ruas Jalan di Indonesia

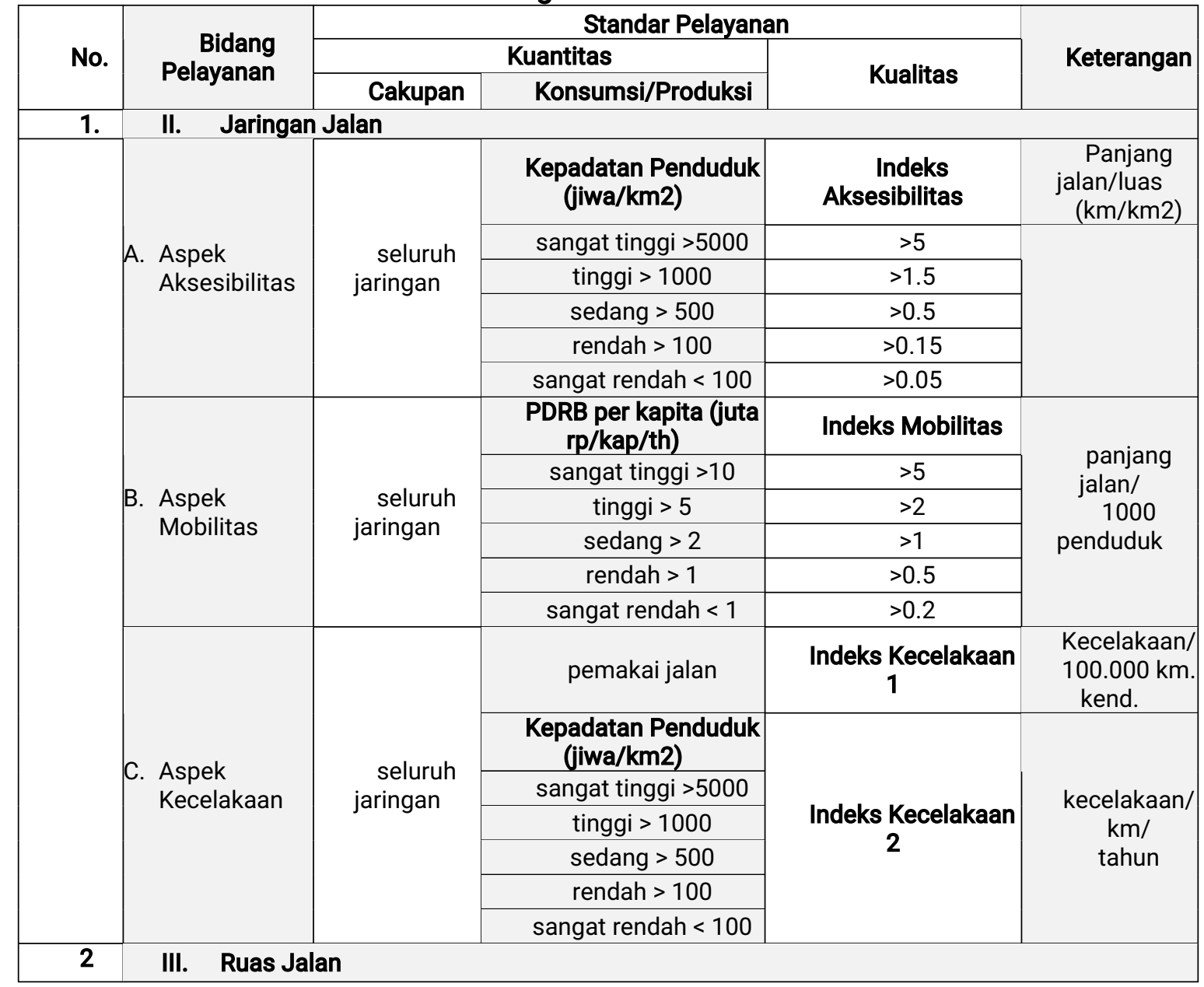




\begin{tabular}{|c|c|c|c|}
\hline \multirow{5}{*}{$\begin{array}{r}\text { A. } \\
\text { Jalan }\end{array}$} & $\begin{array}{l}\text { Lebar Jalan } \\
\text { Min. }\end{array}$ & $\begin{array}{l}\text { Volume Lalulintas } \\
\text { (kend/hari) }\end{array}$ & Kondisi Jalan \\
\hline & $2 \times 7 m$ & $\mathrm{lhr}>20000$ & $\begin{array}{c}\text { sedang; iri < 6; rci }> \\
6.5\end{array}$ \\
\hline & $7 \mathrm{~m}$ & $8000>\mathrm{lhr}>20000$ & $\begin{array}{c}\text { sedang; iri < 6; rci > } \\
6.5\end{array}$ \\
\hline & $6 m$ & $3000>1 \mathrm{hr}>8000$ & $\begin{array}{c}\text { sedang; iri }<8 ; \text { rci }> \\
5.5\end{array}$ \\
\hline & $4.5 \mathrm{~m}$ & $\mathrm{Ihr}<3000$ & $\begin{array}{c}\text { sedang; iri }<8 ; \text { rci }> \\
5.5\end{array}$ \\
\hline \multirow{7}{*}{$\begin{array}{l}\text { B. Kondisi } \\
\text { Pelayanan }\end{array}$} & $\begin{array}{l}\text { Fungsi } \\
\text { Jalan }\end{array}$ & Pengguna Jalan & $\begin{array}{l}\text { Kecepatan Tempuh } \\
\text { Min }\end{array}$ \\
\hline & $\begin{array}{l}\text { arteri } \\
\text { primer }\end{array}$ & $\begin{array}{l}\text { lalu lintas regional } \\
\text { jarak jauh }\end{array}$ & $25 \mathrm{~km} / \mathrm{jam}$ \\
\hline & $\begin{array}{l}\text { kolektor } \\
\text { primer }\end{array}$ & $\begin{array}{l}\text { lalu lintas regional } \\
\text { jarak sedang }\end{array}$ & 20 km/jam \\
\hline & lokal primer & lalu lintas lokal & 20 km/jam \\
\hline & $\begin{array}{r}\text { arteri } \\
\text { sekunder }\end{array}$ & $\begin{array}{l}\text { lalu lintas kota jarak } \\
\text { jauh }\end{array}$ & 25 km/jam \\
\hline & $\begin{array}{l}\text { kolektor } \\
\text { sekunder }\end{array}$ & $\begin{array}{l}\text { lalu lintas kota jarak } \\
\text { sedang }\end{array}$ & $25 \mathrm{~km} / \mathrm{jam}$ \\
\hline & $\begin{array}{c}\text { lokal } \\
\text { sekunder }\end{array}$ & lalu lintas lokal kota & 20 km/jam \\
\hline
\end{tabular}

Sumber: Departemen Kimpraswil, 2001

SPM di bidang jalan ini dikembangkan dalam sudut pandang publik sebagai pengguna jalan, dimana ukurannya merupakan indikator umum (common indicator) yang diinginkan oleh pengguna. Basis SPM dikembangkan dari tiga keinginan dasar pengguna jalan, yakni:

(1) kondisi jalan yang baik (tidak ada lubang)

(2) tidak macet (lancar sepanjang waktu), dan

(3) dapat digunakan sepanjang tahun (tidak banjir waktu musim hujan)

\subsection{Aspek Aksesibilitas Jaringan Jalan di Propinsi NTT}

Aspek aksesibilitas terkait dengan kemudahan suatu wilayah untuk dijangkau, tentu saja dalam hal ini melalui jaringan jalan yang ada. Dalam pengertian tersebut, maka satuan SPM-nya pun berupa proporsi antara panjang jalan yang tersedia dengan luasan wilayah daratan yang harus dilayani atau secara dimensional dipresentasikan oleh besaran $\mathrm{km}$ jalan $/ \mathrm{km}^{2}$ wilayah. Besarnya nilai aspek aksesibilitas atau lebih dikenal sebagai indeks aksesibilitas divariasikan berdasarkan kepadatan penduduk di wilayah tersebut, artinya bahwa tingkat kepadatan penduduk yang berbeda dari beberapa wilayah akan membedakan tingkat kebutuhan jaringan jalan. Tabel $\mathbf{3}$ menyajikan hasil analisis aksesibilitas jaringan jalan di setiap Kabupaten/Kota di NTT. Secara umum, untuk seluruh Kabupaten/Kota di NTT terlihat bahwa jaringan jalan yang ada di propinsi ini, bila dilihat dari sisi kuantitas relatif terhadap luas wilayah dan kepadatan penduduk maka kebutuhan jaringan jalan telah mencukupi atau diatas nilai minimum yang ditetapkan dalam SPM jalan.

Tabel 3 Indeks Aksesibilitas Jaringan Jalan di Setiap Kabupaten/Kota di Propinsi 
NTT

\begin{tabular}{|c|c|c|c|c|c|c|c|c|c|}
\hline \multirow{2}{*}{ No } & \multirow{2}{*}{ Kab/Kota } & \multirow{2}{*}{$\begin{array}{l}\text { Luas } \\
\text { (km2) }\end{array}$} & \multicolumn{2}{|c|}{ Penduduk } & \multirow{2}{*}{$\begin{array}{r}\begin{array}{r}\text { Panjan } \\
\mathrm{g}\end{array} \\
\text { jalan } \\
(\mathrm{km}) \\
\end{array}$} & \multicolumn{4}{|c|}{$\begin{array}{c}\text { Indeks aksesibilitas } \\
(\mathrm{km} / \mathrm{km} 2)\end{array}$} \\
\hline & & & Jumlah & Kpdtn/km2 & & $\begin{array}{l}\text { Eksis } \\
\text { ting }\end{array}$ & $\operatorname{Min}_{i}$ & +1 & $\begin{array}{l}\text { dev } \\
\text { iasi }\end{array}$ \\
\hline 1 & Kabupaten Sumba Barat & $\begin{array}{r}4,051.9 \\
2\end{array}$ & 342,138 & 84 & 1,165 & 0.29 & 0.05 & + & 0.24 \\
\hline 2 & Kabupaten Sumba Timur & $\begin{array}{r}7,000.5 \\
0\end{array}$ & 179,014 & 26 & 1,390 & 0.20 & 0.05 & + & 0.15 \\
\hline 3 & Kabupaten Kupang & $\begin{array}{r}7,178.2 \\
6\end{array}$ & 389,100 & 54 & 1,918 & 0.27 & 0.05 & + & 0.22 \\
\hline 4 & $\begin{array}{l}\text { Kabupaten Timor Tengah } \\
\text { Selatan }\end{array}$ & $\begin{array}{r}3,947.0 \\
0\end{array}$ & 384,930 & 98 & 1,602 & 0.41 & 0.05 & + & 0.36 \\
\hline 5 & $\begin{array}{l}\text { Kabupaten Timor Tengah } \\
\text { Utara }\end{array}$ & $\begin{array}{r}2,669.6 \\
6 \\
\end{array}$ & 190,034 & 71 & 1,009 & 0.38 & 0.05 & + & 0.33 \\
\hline 6 & Kabupaten Belu & $\begin{array}{r}2,445.5 \\
7 \\
\end{array}$ & 259,171 & 106 & 920 & 0.38 & 0.15 & + & 0.23 \\
\hline 7 & Kabupaten Alor & $\begin{array}{r}2,864.6 \\
0\end{array}$ & 158,188 & 55 & 1,279 & 0.45 & 0.05 & + & 0.40 \\
\hline 8 & Kabupaten Flores Timur & $\begin{array}{r}3,079.2 \\
3\end{array}$ & 283,770 & 92 & 1,265 & 0.41 & 0.05 & + & 0.36 \\
\hline 9 & Kabupaten Sikka & $\begin{array}{r}1,731.9 \\
2\end{array}$ & 256,176 & 148 & 980 & 0.57 & 0.15 & + & 0.42 \\
\hline 10 & Kabupaten Ende & $\begin{array}{r}2,064.6 \\
2 \\
\end{array}$ & 231,348 & 112 & 1,026 & 0.50 & 0.15 & + & 0.35 \\
\hline 11 & Kabupaten Ngada & $\begin{array}{r}3,037.8 \\
8\end{array}$ & 218,282 & 72 & 1,355 & 0.45 & 0.05 & + & 0.40 \\
\hline 12 & Kabupaten Manggarai & $\begin{array}{r}7,136.4 \\
0 \\
\end{array}$ & 593,290 & 83 & 2,324 & 0.33 & 0.05 & + & 0.28 \\
\hline 13 & Kota Kupang & 160.34 & 221,095 & 1,379 & 563 & 3.51 & 1.5 & + & 2.01 \\
\hline & PROPINSI NTT & 47,368 & $3,706,536$ & 78 & 16,796 & 0.35 & 0.05 & + & 0.30 \\
\hline
\end{tabular}

Keterangan:

+ = di atas SPM - = di bawah SPM

Sumber: Tamin, Ofyar. 2002

Bilamana dilihat dari besarnya nilai indeks aksesibilitas per Kabupaten/Kota, indeks aksesibilitas eksisting yang ada hampir semuanya berada di bawah angka $1 \mathrm{~km}$ jalan per km2 luas pelayanan (kecuali untuk Kota Kupang yang angkanya telah mencapai 3,51 $\mathrm{km} / \mathrm{km} 2$ ). Artinya bahwa di setiap $\mathrm{km} 2$ wilayah di propinsi NTT hanya tersedia jalan kurang lebih 0,35 km. Katakanlah ruas jalan yang ada tersebut dianggap lurus dan terdistribusi merata di seluruh wilayah maka jaringan jalan yang ada akan tidak terhubungkan. Secara jaringan, dengan memperhatikan ilustrasi pada Gambar $\mathbf{5}$ maka pada dasarnya minimal idealnya setiap bagian wilayah, katakan per $1 \mathrm{~km} 2$, harus terhubungkan dengan wilayah lainnnya. Dengan kata lain, sebenarnya di Propinsi NTT masih membutuhkan adanya penambahan panjang jalan, terutama untuk menjangkau wilayah terpencil. Strategi paling baik untuk menambah akses jalan ke setiap wilayah yang ada di Propinsi NTT adalah dengan memisahkan luas wilayah hutan dan kawasan lindung (yang memang akses ke wilayah tersebut dibatasi) dan kemudian memeriksa keterhubungan wilayah yang dapat dikembangkan dengan jaringan jalan ke wilayah lainnya.

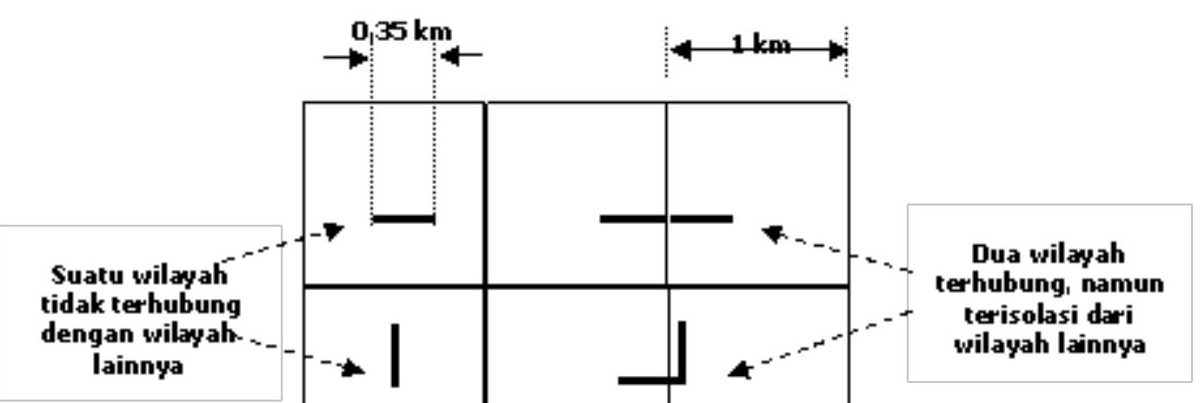




\section{Gambar 5 llustrasi Kondisi Aksesibilitas di Propinsi NTT}

\subsection{Aspek Mobilitas Jaringan Jalan di Propinsi NTT}

Aspek mobilitas terkait dengan kemudahan seseorang untuk melakukan perjalanan, tentu saja dengan menggunakan jaringan jalan yang ada. Dalam pengertian tersebut, maka satuan SPM-nya pun berupa proporsi antara panjang jalan yang tesedia relatif terhadap jumlah penduduk yang harus dilayani (dalam hal ini per 1000 penduduk), atau dalam bahasa teknis diekspresikan dengan besaran $\mathrm{km}$ jalan/1000 penduduk. Besarnya nilai aspek mobilitas atau lebih tepat dikatakan sebagai indeks mobilitas ini divariasikan menurut PDRB perkapita penduduk di wilayah yang bersangkutan, artinya bahwa semakin tinggi PDRB suatu komunitas penduduk maka kebutuhan perjalanan per orangnya akan bertambah dan oleh karena itu kebutuhan akan jaringan jalan juga akan bertambah.

Tabel 4 Indeks Mobilitas Jaringan Jalan di Setiap Kabupaten/Kota di Propinsi NTT

\begin{tabular}{|c|c|c|c|c|c|c|c|c|}
\hline \multirow{2}{*}{$0^{N}$} & \multirow[t]{2}{*}{ Kab/Kota } & \multicolumn{2}{|c|}{$\begin{array}{c}\text { PDRB Nilai } \\
\text { Konstan } 1993 \text { (jt Rp) }\end{array}$} & \multirow{2}{*}{\begin{tabular}{|c|}
$\begin{array}{l}\text { Panjang } \\
\text { jalan }\end{array}$ \\
(km) \\
\end{tabular}} & \multicolumn{4}{|c|}{$\begin{array}{r}\text { Indeks mobilitas } \\
(\mathrm{km} / 000 \text { penduduk) }\end{array}$} \\
\hline & & Jumlah & Perkapita & & Eksisting & Minimum & $+/-$ & Deviasi \\
\hline 1 & Kabupaten Sumba Barat & 170,653 & 0.50 & 1,165 & 3.41 & 0.2 & + & 3.21 \\
\hline 2 & Kabupaten Sumba Timur & 164,803 & 0.92 & 1,390 & 7.76 & 0.2 & + & 7.56 \\
\hline 3 & Kabupaten Kupang & 349,302 & 0.90 & 1,918 & 4.93 & 0.2 & + & 4.73 \\
\hline 4 & $\begin{array}{lll}\text { Kabupaten } & \text { Timor } & \text { Tengah } \\
\text { Selatan } & & \\
\end{array}$ & 218,175 & 0.57 & 1,602 & 4.16 & 0.2 & + & 3.96 \\
\hline 5 & $\begin{array}{lll}\text { Kabupaten } & \text { Timor } & \text { Tengah } \\
\text { Utara } & & \\
\end{array}$ & 126,363 & 0.66 & 1,009 & 5.31 & 0.2 & + & 5.11 \\
\hline 6 & Kabupaten Belu & 165,784 & 0.64 & 920 & 3.55 & 0.2 & + & 3.35 \\
\hline 7 & Kabupaten Alor & 111,657 & 0.71 & 1,279 & 8.09 & 0.2 & + & 7.89 \\
\hline 8 & Kabupaten Flores Timur & 175,972 & 0.62 & 1,265 & 4.46 & 0.2 & + & 4.26 \\
\hline 9 & Kabupaten Sikka & 190,689 & 0.74 & 980 & 3.83 & 0.2 & + & 3.63 \\
\hline 10 & Kabupaten Ende & 183,479 & 0.79 & 1,026 & 4.43 & 0.2 & + & 4.23 \\
\hline 11 & Kabupaten Ngada & 159,945 & 0.73 & 1,355 & 6.21 & 0.2 & + & 6.01 \\
\hline 12 & Kabupaten Manggarai & 317,277 & 0.53 & 2,324 & 3.92 & 0.2 & + & 3.72 \\
\hline 22 & Kota Kupang & 479,291 & 2.17 & 563 & 2.55 & 1.0 & + & 1.55 \\
\hline & PROPINSI NTT & $2,834,510$ & 0.76 & 16,796 & 4.53 & 0.2 & + & 4.33 \\
\hline
\end{tabular}

\section{Keterangan:}

$+=$ di atas SPM $\quad-=$ di bawah SPM

Sumber: Tamin, Ofyar. 2002

Hasil estimasi indeks mobilitas jaringan jalan untuk setiap Kabupaten/Kota di Propinsi NTT disampaikan pada Tabel 4. Secara umum, di setiap Kabupaten/Kota di Propinsi NTT sudah berada pada tingkatan di mana kebutuhan penduduk akan mobilitas dengan menggunakan jaringan jalan sudah terpenuhi Namun demikian jika dicermati bahwa pada dasarnya PDRB perkapita di Propinsi NTT masih cukup rendah hanya sekitar 35\% dibandingkan dengan kondisi di seluruh Indonesia yang saat ini telah mencapai 
sekitar 2,1 juta Rp/penduduk/tahun.

\subsection{Konsep Pengembangan Infrastruktur Transportasi di Propinsi NTT}

Jika dilihat dari Rencana Tata Ruang Wilayah Propinsi Nusa Tenggara Timur, maka di Propinsi ini terdapat 3 kota pada Hirarki/Jenjang I, 14 kota dengan Hirarki/Jenjang II, dan 29 kota dengan Hirarki/Jenjang III. Selain itu propinsi NTT juga berbatasan dengan Propinsi NTB di sebelah barat dan di sebelah timur dengan Propinsi Maluku dan Negara Timor Leste. Pedoman untuk menentukan fungsi jalan yang menghubungkan kota-kota tersebut dilakukan dari hirarki kota yang tertinggi yang akan dihubungkan. Adapun prosesnya sebagai berikut:

(1) Kota Hirarki I harus dihubungkan dengan Kota Hirarki I lain dan dengan Kota Hirarki II oleh rute jalan-jalan yang berfungsi arteri primer.

(2) Kota Hirarki II harus dihubungkan dengan Kota Hirarki II lain dan dengan Kota Hirarki III oleh rute jalan-jalan yang berfungsi kolektor primer.

(3) Jika letak suatu kota merupakan jalur atau rute yang menghubungkan dua kota yang hirarkinya lebih tinggi maka diasumsikan bahwa kota tersebut telah terhubungkan dengan sistem fungsi jalan yang benar.

Problem yang timbul untuk menetapkan fungsi jalan di propinsi NTT ini adalah bahwa kondisi geografisnya yang berupa kepulauan. Dengan kondisi ini maka jaringan jalan yang ada akan dihubungkan dengan lintas penyeberangan dengan fungsi yang sama seperti fungsi jalan yang dihubungkannya. Dengan menggunakan pengertian tersebut maka idealisasi konsep pengembangan infrastruktur transportasi secara skematis untuk Propinsi NTT dapat digambarkan seperti pada Gambar 6.

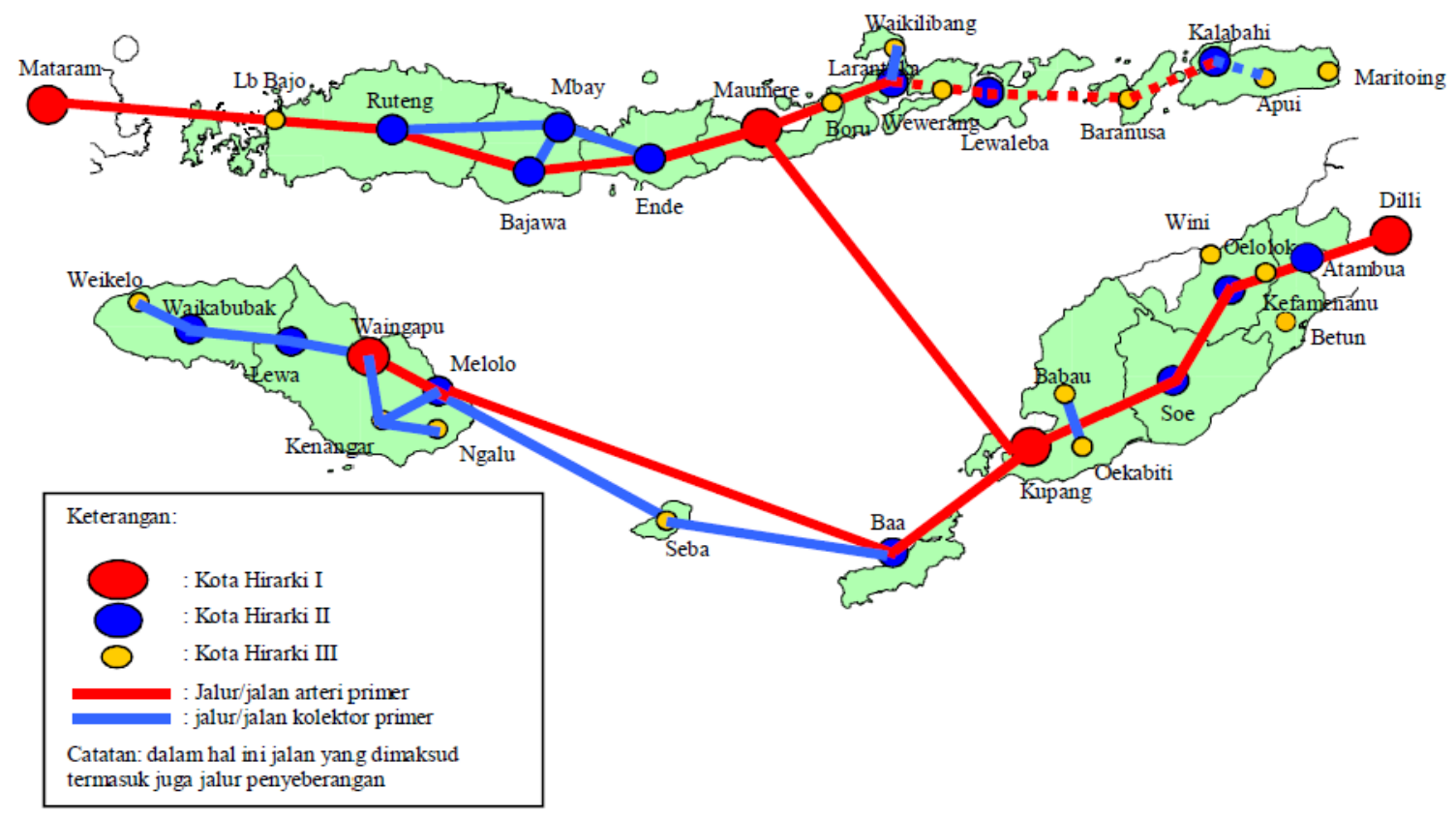

Gambar 6 Idealisasi Konsep Pengembangan Infrastruktur Transportasi

\section{PENUTUP} di Propinsi NTT

\subsection{Kesimpulan}

Berdasarkan paparan makalah ini maka dapat disimpulakn bahwa: 
1. Dokumen MP3EI sesungguhnya harus dipahami oleh 3 pilar pelaku MP3EI (pemerintah dan pemerintah daerah, pelaku bisnis, dan akademisi) sebagai dokumen kerja yang komplemen, bukan pengganti, dari dokumen RPJPN tahun 2005-2025, sekaligus sebagai salah satu acuan penyusunan RTRW Propinsi/Kabupaten/Kota;

2. Secara umum, indeks aksesibilitas eksisting untuk seluruh Kabupaten/Kota di NTT hampir semuanya berada di bawah angka $1 \mathrm{~km}$ jalan per $\mathrm{km} 2$ luas pelayanan (kecuali untuk Kota Kupang yang angkanya telah mencapai $3,51 \mathrm{~km} / \mathrm{km} 2$ ). Artinya bahwa jaringan jalan yang ada di propinsi NTT, secara kuantitas relatif terhadap luas wilayah dan kepadatan penduduk, kebutuhan jaringan jalannya telah mencukupi atau diatas nilai minimum yang ditetapkan dalam SPM jalan, namun sesungguhnya belum terhubungkan antara satu wilayah dengan wilayah lainnnya.

3. Hasil estimasi indeks mobilitas jaringan jalan untuk setiap Kabupaten/Kota di Propinsi NTT berada pada tingkatan dimana kebutuhan penduduk akan mobilitas dengan menggunakan jaringan jalan sudah terpenuhi. Namun demikian, jika dicermati maka pada dasarnya PDRB perkapita di Propinsi NTT masih cukup rendah yakni hanya sekitar $35 \%$ dibandingkan dengan kondisi di Indonesia yang saat ini telah mencapai sekitar 2,1

juta Rp/penduduk/tahun. Hal ini mengingat jaringan jalan tidak terhubung antar satu wilayah dengan wilayah lain akibat hambatan geografis (kepulauan).

\subsection{Saran}

1. Problem yang timbul untuk menetapkan fungsi jaringan jalan di propinsi NTT ini adalah kondisi geografisnya yang berupa kepulauan, sehingga perlu dipikirkan aspek multi moda yang mantap sebagai ciri jaringan transpotasi di Propinsi NTT yang berbentuk kepulauan. Dengan demikian maka pemenuhan syarat SPM jaringan jalan di NTT tidak saja terbatas pada ukuran kuantitas tetapi berdampak pada peningkatan pertumbuhan ekonomi di berbagai kawasan di NTT.

2. Jika dilihat dari RTRW Propinsi Nusa Tenggara Timur dan dikaitkan dengan Kebijakan MP3EI maka di Propinsi ini terdapat 3 kota pada Hirarki/Jenjang I, 14 kota dengan Hirarki/Jenjang II, dan 29 kota dengan Hirarki/Jenjang III. Jaringan jalan yang ada harus dihubungkan dengan lintas penyeberangan dengan fungsi yang sama seperti fungsi jalan. Khusus untuk daerah perbatasan, maka perlu dipertimbangkan untuk pengembangan kawasan di Morotaing, Apui, Wini, Oelolok dan Betun sebagai kota dengan Hirarki/Jenjang III.

\section{DAFTAR PUSTAKA}

Dardak, H. (2005) Kebijakan Penataan Ruang dalam Penyelenggaraan Infrastruktur KePUan, Makalah, Kuliah Umum Kedinasan-Pusbiktek, Dirjen Tata Ruang, Jakarta.

Departemen Kimpraswil, (2001) Standar Pelayanan Minimum Jalan, Dirjen Bina Marga, Jakarta.

Kementerian Koordinator Bidang Perekonomian (2011) Pokok-pokok Pelaksanaan MP3EI Tahun 20011-2025, Rakernas Kementerian KUKM, Jakarta.

LP-ITB (2001) Penelitian Pengembangan Sistem Transportasi Wilayah Terpadu di Propinsi Jawa Barat, Lembaga Penelitian, ITB.

Peraturan Presiden Nomor 32 Tahun 2011 tentang Masterplan Percepatan dan Perluasan Pembangunan Ekonomi Indonesia (MP3EI) Tahun 2011-2025.

Tamin, O.Z. (2001) Konsep Pengembangan Sistem Transportasi Wilayah di Era Otonomi Daerah, Seminar Nasional 'Strategi Pemenuhan Kebutuhan dan Penentuan Prioritas Pengembangan 
Infrastruktur Wilayah', Ditjen Bangda,

Depdagri-Bappenas, Jakarta, 26

November 2001.

Tamin, O.Z. (2000) Perencanaan dan Pemodelan Transportasi, Edisi 2, Penerbit ITB.

Undang-undang Nomor 17 Tahun 2007 tentang Rencana Pembangunan Jangka Panjang Nasional (RPJPN) Tahun 2005-2025.

Undang-undang Nomor 38 Tahun 2004 tentang Jalan.

Undang-undang Nomor 32 Tahun 2004 tentang Pemerintahan Daerah

Undang-undang Nomor Tahun 1992 tentang Penataan Ruang

Widayatin, S. (2005) Pembiayaan Infrastruktur, Kuliah Umum KedinasanPusbiktek, Staf Ahli Menteri PU, Jakarta 
